\title{
Enhancing Teacher Training Quality Through Teaching Practice: Perceptions and Perspectives
}

\author{
Leila Benstaali \\ Abdelamid Ibn Badis University, Mostaganem
}

\begin{abstract}
Education has become the concern of stakeholders throughout the world. It has prompted calls for reform to teachers' practices in order to improve the standard of the teaching/learning process. This requires adequate preparation of prospective teachers to meet the challenges of teaching. But the question of how teaching is learnt and how programmes of professional preparation can contribute to the development of teacher education elicits quite different answers. The present paper explores the issues that emerge in the field of education and the difficulties that teachers face in the classrooms. It also describes the field experience of future teachers to help in the identification of their training needs. To render teacher training more effective and achieve better teacher quality, some recommendations are provided. They might be of great usefulness to policymakers as potential areas to address the challenges of developing a high quality, motivated and professional teaching force at the school level.
\end{abstract}

Keywords: quality; teaching practice; training 